\title{
Separation and Removal of Faeces and Urine using Filter Nets under Slatted Floors in Piggeries
}

\author{
W. KROOUSMA*
}

\begin{abstract}
This paper discusses the development and perliormance of a combined system for the separation and removal of dung and liquid in piggeries. The system separates the faeces and urine, directly after production, by a filter net situated under th: slats which is removed from the pens daily. About $35 \%$ of the total production of taeces and urine is separated as a solid and this is easy to store and transport.

The remaining liquid contains only $25 \%$ of the original $\mathrm{BOD}_{5}$ and is less polluting than the original mixture. The system allows the usc of straw to improve animal comfort and to reduce heating costs in winter. The improved environment brought about by removal of dung and urine allows lower ventilation rates in winter and causes lower odour emission.

The extra investment for the filter net system, compared with the usual underslat slurry system, is related to the number of pigs and lay-out of the piggery. The investment in mechanical components can be partly offset by shallower. less expensive channels and by not installing a heating system.
\end{abstract}

\section{Introduction}

During the last ten years the number of pigs and poultry in the Netherlands has increased enormously. This was made possible by a growing market for the products and developments in the technology and management of large pig units. These developments have increased the size of the units and the efficiency of labour use. Limits to farm size are seldom determined by farm waste disposal, air pollution or well-being of the animals.

At present there are local regions where there is a surplus of slurry. So-called manure banks stimulate the use of slurry in areas with arable crops with the help of information and grants. However, the disposal of pig slurry is uncconomic over distances of more than $20 \mathrm{~km}$ since the slurry has low value as a fertilizer. Separation offers the possibility of obtaining solid manure with a high fertilizer value and a liquid with a low value. Thus it becomes more worthwhile to transport the solid manure over longer distances for arable crop production and to put the liquid on land in areas adjacent to the production units.

Slurry can be separated by simple machines without the addition of flocculants, ${ }^{1}$ but the separation efficiency is low. The degree of separation can be improved by use of more complicated separators and adding flocculants. ${ }^{2.3}$ but the costs, $£ 3.45$ to $£ 4.50$ per pig place for an annual slurry production of $1.5 \mathrm{~m}^{3}$ per pig place per annum, are high. Research to separate the faeces directly from the urine has been carried out but the separation efficiency and the practical use are unknown. ${ }^{4,5}$ Although research was aimed mainly at reducing transport costs, there were other motives to separate directly after production of faeces and urine. In modern labour saving housing systems, the floor is totally or partly slatted and the slurry is stored in channels underneath the slats. The use of straw for bedding presents difficulties because of its accumulation under the slats.

Because litter is absent, artificial heating may be needed to obtain optimum temperature for the pigs with a resulting increase in gas consumption and energy costs. ${ }^{6}$ Research has shown that

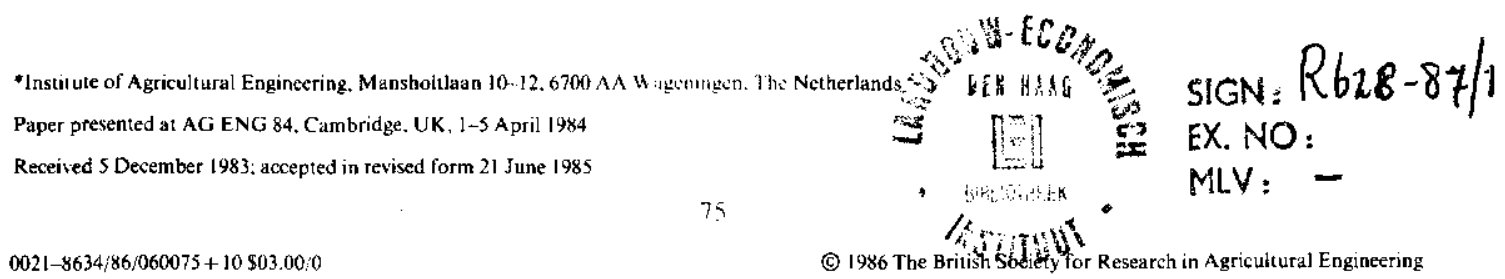


a layer of straw on a concrete floor has a high thermal resistance and so can save energy costs. Secondly straw provision ${ }^{8.9}$ contributes to the well-being of the animals since pigs play with and eat some of the straw.

Under-slat storage also influences environment within the house because odorous gases are released from the slurry. It is known that in stalls with daily removal of faeces and urine the conditions for animal hygiene and health are better thin in stalls with underslat storage. ${ }^{10}$ In the latter stalls the ventilation rate must be increased to produce a good climate ${ }^{11}$ but it also means that energy for heating will be increased. From an available computer program, ${ }^{12}$ it was calculated that in a theoretical case $(30 \mathrm{~kg}$ pigs during the whole year in a pen with a half-slatted floor and a stall temperature of $18^{\circ} \mathrm{C}$ ) by raising the ventilation rate from 0.33 to $0.50 \mathrm{~m}^{3}$ (kg live weight $)^{-1} \mathrm{~h}^{-1}$, the gas consumption increased from 0.79 to $6.40 \mathrm{~m}^{3} /$ head year.

All the above factors combined to foster the objective for IMAG of developing a reliable combined manure filter and removal system for piggeries with half-slatted floors.

\section{Preliminary research}

2.1. Equipment

The first experiments ${ }^{\mathbf{1 3}-14}$ were carried out under a slatted floor in a pen with eight pigs. The aim of this research was to examine five synthetic filter nets with various mesh sizes, a convex belt and an inclined plane for their suitability in separating faeces and urine in piggeries.
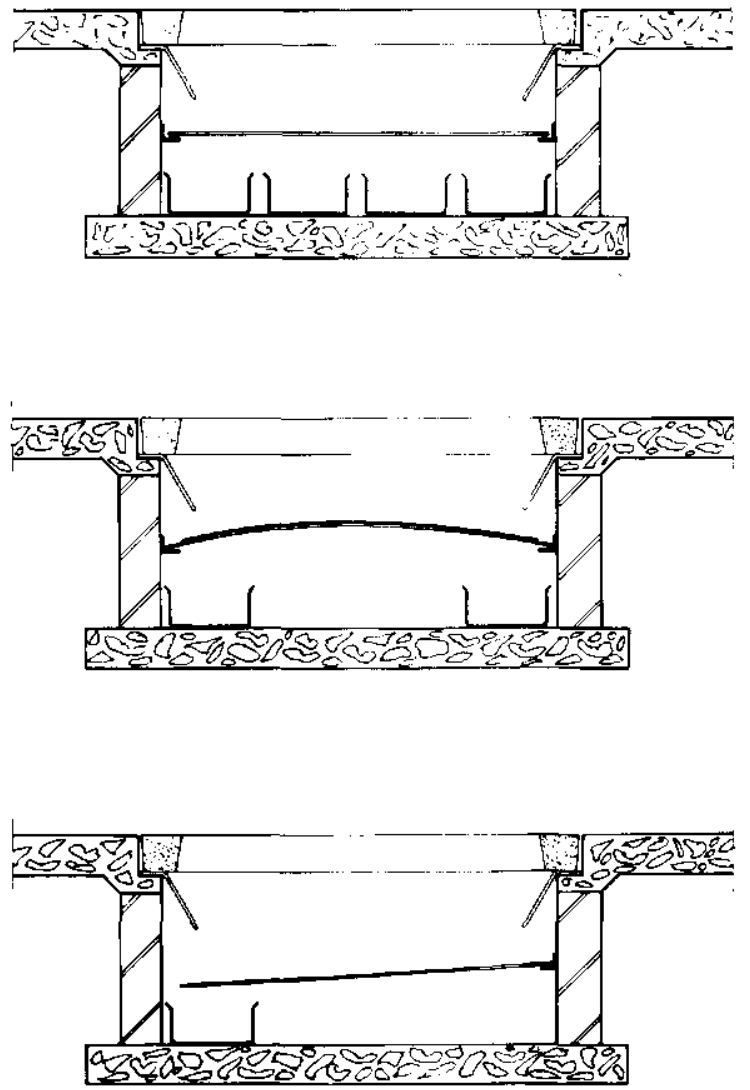

Fig. 1. Three different separation methods used in preliminaw work. The urine was collected in troughs and the faeces were collected (top) on a filter net (middle) on a convex belt and (bottom) on an inclined plane 
The mesh sizes of the filter nets were respectively $0.08 \times 0.90 \mathrm{~mm}, 0.78 \times 0.78 \mathrm{~mm}$, $0.85 \times 1.15 \mathrm{~mm}, 2.00 \times 5.00 \mathrm{~mm}$ and $3.50 \times 3.50 \mathrm{~mm}$. The inclined plane and the convex belt had a gradient of $3 \%$. Fig. 1 shows the schematic design of the different separation techniques. To remove the faeces, the synthetic nets and the convex belt were pulled from underneath the slatted floor with a hand operated winch. The faeces were scraped manually off the inclined plane. The urine was, dependent on the system, collected in one or more troughs. Every 24 hours, the amounts of faeces and urine were weighed and sampled and the composition and separation efficiency were determined. The results of the separation tests and judgements of the suitability of the different materials under practical circumstances led to the decision to use filter nets of $0.08 \times 0.90 \mathrm{~mm}$ and $0.78 \times 0.78 \mathrm{~mm}$ and the convex belt for a mechanized filter and manure removal system.

Table 1

Average composition of faeces and urine after separation by a filter net $(0.78 \times 0.78 \mathrm{~mm})$

\begin{tabular}{l|r|r}
\hline & Faeces & Urine \\
\hline d.m. content \% & 32.50 & 1.92 \\
crude ash \% dry matter & 25.70 & 63.10 \\
$\mathrm{~N}-\mathrm{Kj}$ (total Kjeldahl) \% & 1.24 & 0.34 \\
$\mathrm{NH}_{4}-\mathrm{N}$ (ammonia) \% & 0.34 & 0.35 \\
$\mathrm{P}_{2} \mathrm{O}_{5} \%$ & 1.64 & 0.05 \\
$\mathrm{~K}_{2} \mathrm{O} \%$ & 0.85 & 0.62 \\
$\mathrm{CaO} \%$ & 1.45 & 0.04 \\
$\mathrm{MgO} \%$ & 0.48 & 0.02 \\
$\mathrm{Cu} . \mathrm{p} . \mathrm{m}$. & 189 & 2.50 \\
pH & - & $9 \cdot 1$ \\
\hline
\end{tabular}

\subsection{Composition of faeces and urine}

In Table 1 the average composition is recorded from three samples of faeces and urine for the net with a mesh size of $0.78 \times 0.78 \mathrm{~mm}$. From Table 1 it is evident that the percentages of minerals in the faeces are high. In the urine the percentages are lower except for potassium.

\subsection{Separation efficiency}

Separation efficiency provides a measure of the effectiveness of the filter in separating a particular component from the faeces and urine. The object of slurry separation is to remove as much of the solids as possible.

Fig. 2 shows the results for the filter net of mesh size $0.78 \times 0.78 \mathrm{~mm}$. These results are based on an average of three samples which were sampled during 24 hour observation periods in the course of the fattening period and were calculated using the following formula:

$$
S_{i}=\frac{F Q_{\text {if }}}{F Q_{\text {if }}+U Q_{i \mathrm{u}}} \times 100 \%
$$

where

$S_{i}=$ the separation efficiency,

$F=$ the quantity of faeces in $\mathrm{kg}$,

$U=$ the quantity of urine in $\mathrm{kg}$,

$Q_{i f}=$ the content of $i$ in the faeces in $\mathrm{g} / \mathrm{kg}$

$Q_{\text {iu }}=$ the content of $i$ in the urine in $\mathrm{g} / \mathrm{kg}$

$i$ may be kg, d.m., ash, $\mathrm{N}-\mathrm{Kj}, \mathrm{NH}_{4}-\mathrm{N}, \mathrm{P}_{2} \mathrm{O}_{5}, \mathrm{~K}_{2} \mathrm{O}, \mathrm{CaO}, \mathrm{MgO}, \mathrm{Cu}, \mathrm{BOD}_{5}, \mathrm{COD}$. 


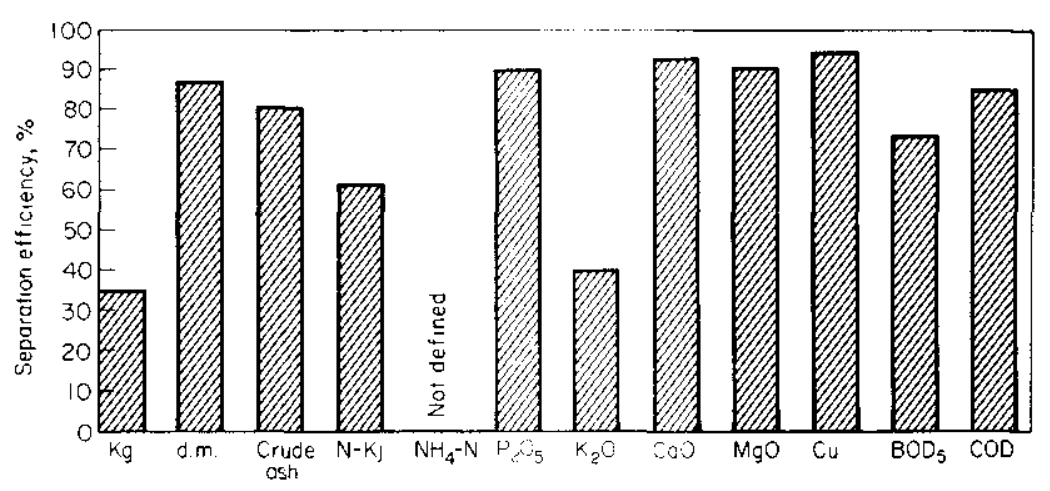

Fig. 2. Separation efficiency (in faeces) for net of mesh size $0.78 \times 0.78 \mathrm{~mm}$

In Fig. 2, the shaded part of the component is in the faeces retained by the filter, while the remainder appears in the urine. From Fig. 2 it is apparent that about $35 \%$ of the total faeces and urine is removed as a solid. It should be noted here that the pigs were given wet feed without any extra drinking water. In pens where animals are fed with dry feed and have automatic provision for drinking water, the quantity of urine will be greater, since where pigs use drinkers, some water will be spilt and will flow into the slurry channel. It is evident that many minerals are separated with the manure. For a number of minerals, $\mathrm{P}_{2} \mathrm{O}_{5}, \mathrm{CaO}, \mathrm{MgO}$ and $\mathrm{Cu}$, it amounts to more than $90 \%$. Nitrogen and potassium were separated in smaller, amounts, about $60 \%$ and $35 \%$ respectively being retained in the solid.

\subsection{Dry matter (d.m.) content of the faeces}

To separate pig slurry, the mixture of faeces. urine and spilt water is pumped to a separator and depending on mesh size, pressure and flocculants a part of the dry matter is separated as a solid, while another part stays in the liquid. Solids of pig slurry consist mainly of the bigger particles of the slurry while most of the colloids are in the liquid. Normally the solids are stackable at dry matter contents of $20 \%$ and upwards.

This is in contrast to the solids produced from the filter system. In this system all the faeces, with dry matter contents varying between 25 and $35 \%$, are retained in the original form. Only a very small part is lost at the moment when the urine is produced and filters by the net. The manure on the filter with all the colloids in it cannot be stacked but this may be overcome by adding chopped straw daily on the solid floor $(50$ to $100 \mathrm{~g} / \mathrm{pig})$ so that a stackable mixture remains behind on the belt.

\section{The pilot scale installation}

\subsection{Lay-out of the piggery}

Fig. 3 and Fig. 4 show respectively piggeries with longitudinal and transverse channels with partly slatted floors. In our experiments the filter installation was installed in both types of stalls. The faeces mixed with the wasted straw from the lying area were removed every day by a transport belt in the dung gutter (B) and stacked on top of the covered pit (A). The urine flows through the liquid gutter $(C)$ into the underground storage tank $(A)$.

\subsection{The mechanized filter installation}

A combined filter and manure removal system must be completely reliable, since it is not easy to make repairs under the slats. In spite of good separation results the convex belt was not reliable so this experiment was terminated. After 2 to 3 years of experience with two different 


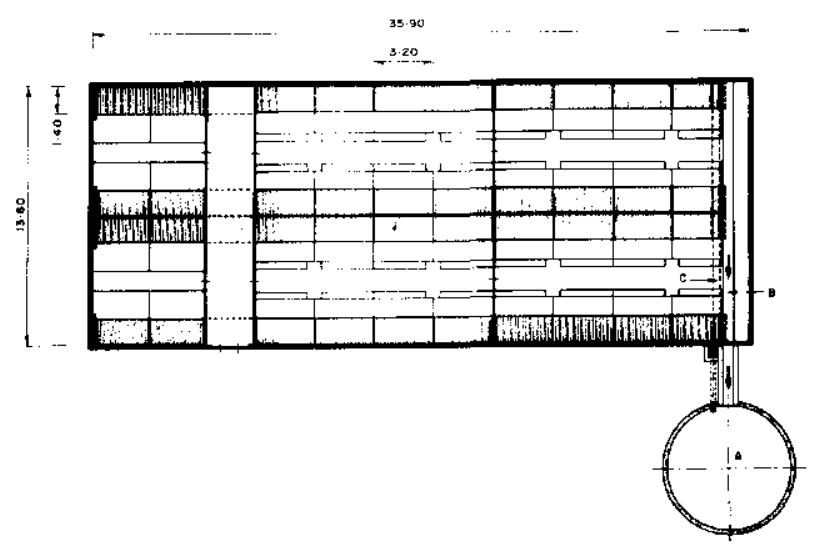

Fig. 3. Plan of the filter system in a piggery with longiludinal channels. A, storage for farmyard manure and liquid; $\dot{B}$, dung guttr: $C$, liquid gutter

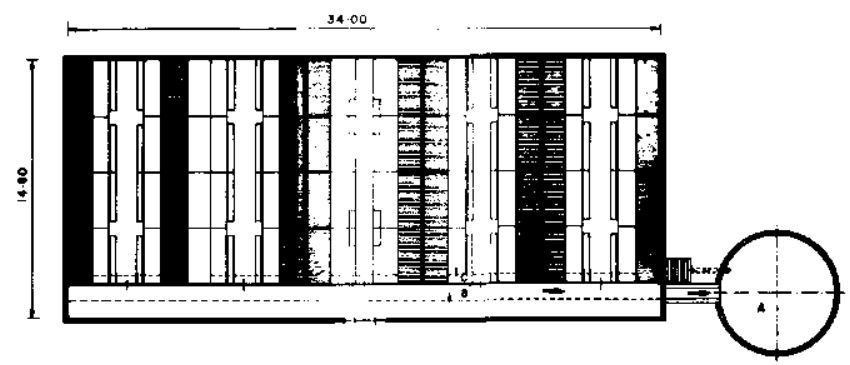

Fig. 4. Plan of the filter system in a piggery with transverse channels. A, storage for farmyard manure and liquid; $B$, dung gutter; $C$, liquid gutter

filter nets a well working system has been developed. Fig. 5 shows a schematic diagram of the filter system installed under the slatted floor. In the channel under the slats, two angle sections (A) are attached one above the other and fixed over the whole length to both walls. These are covered from above with protective plates (B) joined underneath the slats.

With regard to filtering, clogging and cleaning, it was found that a polyethylene net of mesh size $0.78 \times 0.78 \mathrm{~mm}$ was superior to a net of mesh size $0.08 \times 0.90 \mathrm{~mm}$. The filter net (C) is provided with steel strips across the net at $1.0 \mathrm{~m}$ intervals. These strips extend from the net on both sides and are supported by the angle section (A). During the day, the faeces which have fallen through the slats remain on the net, while the urine is filtered through. During the mucking out process, the filter net (C) is drawn at a speed of about $10 \mathrm{~m} / \mathrm{min}$ over a roller (D) situated at the front of the piggery. A brush roller $(\mathrm{H})$ assists removal of the faeces from the filter net. During mucking out the filter net with the strips slides from the upper angle section over the front roller to the bottom angle section.

Two types of driving units (E) are being investigated. In the first case, two motors of $0.75 \mathrm{~kW}$ are placed at the back end of the piggery and are joined to the net via a stainless steel wire (F). When switched on, one draws the net (C) over the front roller (D) back into the pen. During the operation the faeces fall from the net on to the transport belt $(G)$ which carries the faeces outside. At the end, the first motor switches off automatically and the second switches on and draws the filter net back to its original position. In the second case, a $0.75 \mathrm{~kW}$ motor with a pre-set springloaded tension apparatus is installed. The stainless steel wire $(F)$ is wound 4 to 5 times around a drum. When the motor is switched on, the wire tightens and the filter net (C) is drawn backwards and forwards over the front roller (D). 

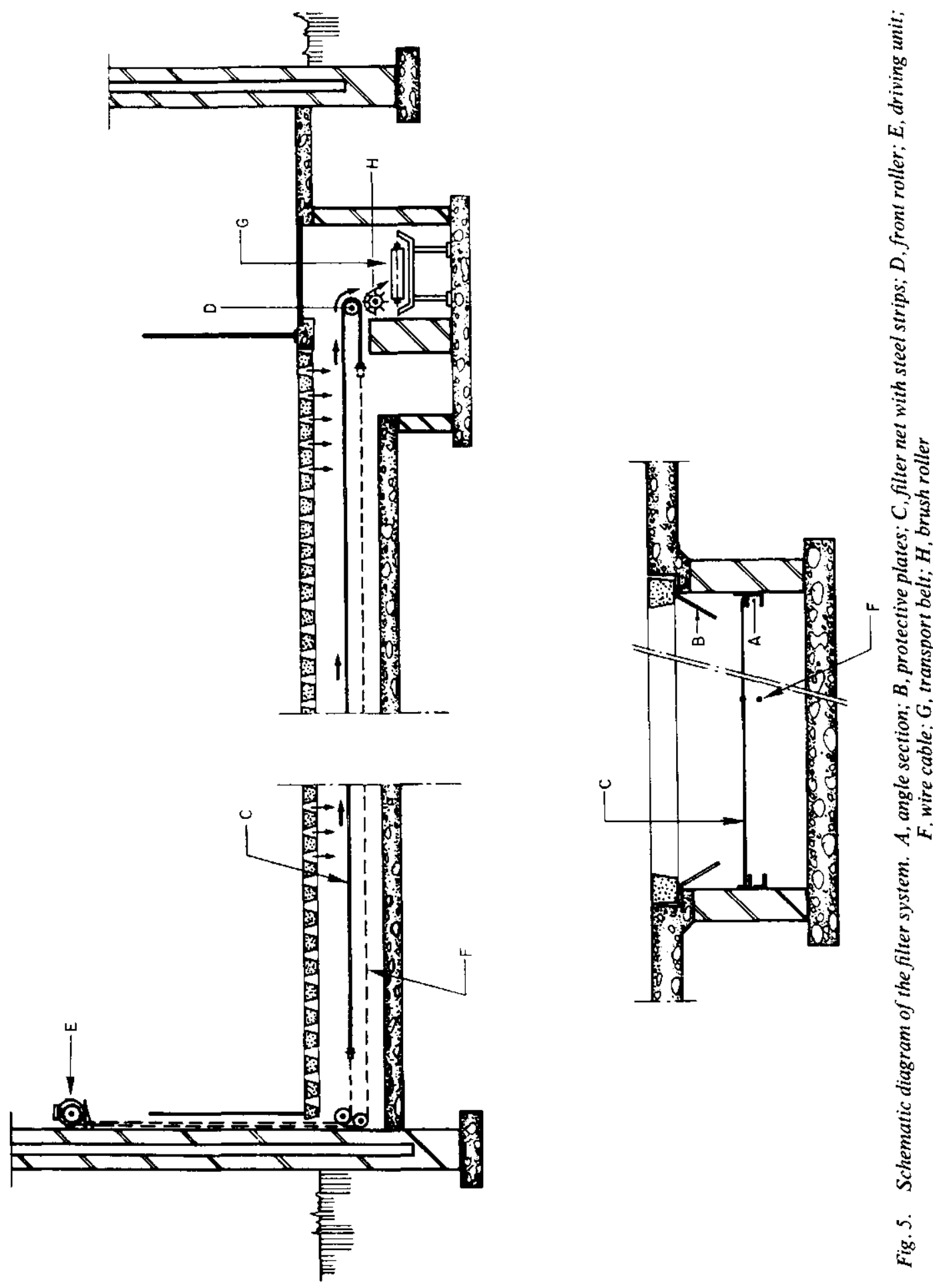


\subsection{Cleaning}

The net has to be cleaned for two reasons, first. daily cleaning to remove faeces during mucking out and second, periodic cleaning to remove gradual blockages of the net through puddling and drying-out of faeces not removed during daily cleaning.

After experimenting with different methods, such as an air compressor, brush roller and power hose washer amongst others, it appeared that for daily cleaning a brush roller was the best soiution. The brush roller $(\mathrm{H})$, situated under the front roller, rotates during the mucking out in the opposite direction to the roller. It became evident that at low speed (less than $200 \mathrm{rev} / \mathrm{min}$ ) the brush quickly became fouled, but at higher speed it was self-cleaning. For this reason the brush is driven by a $0.2 \mathrm{~kW}$ electric molor at about $500 \mathrm{rev}$ min. For periodic cleaning, the simplest way is with a high-pressure hose while the net is drawn backwards and forwards. Although this latter method can also be used for daily cleaning, it has the disadvantage that the amount of water used leads to a greater liquid production.

\section{Results and discussions}

4.1. Ust of the faces and urine

Separation produces two different products, namely, solid manure (faeces and straw) and liquid (urine, water and faecal matter). For field spreading, manuring of grassland is limited by the $\mathrm{K}_{2} \mathrm{O}$ content, while on arable land the quantity of nitrogen needs to be taken into account. ${ }^{15}$ From Fig. 2 it appears that by separation a great part of the potassium and nitrogen is removed with the solids. This means that in comparison with manuring by unseparated slurry, the application of urine on grassland can be raised by about $35 \%$ while on cropland it can be doubled. In applying solid manure to cropland the $\mathrm{Cu}$-content needs to be taken into account. Depending on the $\mathrm{Cu}$-status of the soil, 0 to $6 \mathrm{~kg} \mathrm{Cu} / \mathrm{ha}$ is advised. By fertilizing with $10 \mathrm{t} / \mathrm{ha}$ of solid manure about $3 \mathrm{~kg} \mathrm{Cu} / \mathrm{ha}$ is administered. Because only a small amount of copper is taken up by plants and lost through drainage, the application of solid manure needs to be spread over a few years if $\mathrm{Cu}$ is not to accumulate in the soil.

\subsection{Production of mamure which can be stacked}

As already mentioned, separated faeces cannot be stacked. In the experiments 50 to $100 \mathrm{~g}$ chopped straw per animal was provided daily and the chopped straw did not block the slats. The litter was strewn on the lying area. To restrict waste of straw, a removable division was constructed between slatted and lying area. This construction is usable for pigs up to $50 \mathrm{~kg}$ but for older pigs the division must be removed to provide sufficient lying space. Some of the straw provided is wasted through the slats and together with the faeces, stackable farmyard manure is obtained. In pens with breeding sows, because their manure is drier, less straw is needed than for fattening pigs.

\subsection{Odour emissions}

It can be concluded that separation and removal of urine and faeces from a piggery result in a reduction of odorous components. ${ }^{16}$ This might result in a decrease of the perceived odour as compared with a housing system with underslat slurry storage.

In order to obtain a reliable figure for the aztual odour reduction, measurements were carried out. Samples of ventilation air from a piggery with underslat slurry storage as well as a piggery with filter nets were taken on a number of different occasions. All samples were collected in bags made from FEP-Teflon. Odour judgements were made the following day using a dilution apparatus (olfactometer) and a group of observers (panel). Since the establishment of the odour intensity is a time consuming affair, ${ }^{17}$ it has become practice in Dutch agricultural odour research to concentrate on the establishment of the odour threshold. ${ }^{18}$ The odour threshold is defined as that dilution of odorous air which cannot be distinguished from odourless air by $50 \%$ 
Table 2

Odour measurements

\begin{tabular}{|c|c|c|c|c|c|c|c|c|}
\hline \multirow[b]{2}{*}{ Date of sampling } & \multicolumn{4}{|c|}{ Piggery with weturathon } & \multicolumn{4}{|c|}{$\begin{array}{c}\text { Piggery with under-slat } \\
\text { slurry storage }\end{array}$} \\
\hline & 24.5 .83 & $31.5 \times 3$ & 14.9 .83 & 28.10 .83 & 24.5 .83 & 31.5 .83 & 14.9.83 & 28.10 .83 \\
\hline Number of pigs & 158 & 158 & 158 & 157 & 300 & 275 & 279 & 279 \\
\hline Average liveweght (kg) & 75 & 80 & 45 & 75 & 80 & 90 & 45 & 85 \\
\hline Ventilation rate $\left(\mathrm{m}^{3 \mathrm{~kg}-1} \mathrm{~h}^{-1}\right)$ & 0.61 & 0.93 & 0.89 & 0.47 & 0.21 & $0 \cdot 54$ & 0.52 & 0.57 \\
\hline Dilutions to threshold ( $\mathrm{DT}_{50}$ ) & 770 & 1010 & 817 & 1630 & 4130 & 3070 & 2820 & 2900 \\
\hline Total odour emission $10^{3}\left(\mathrm{DT}_{50} \mathrm{~m}^{3 \mathrm{~h}-1}\right)$ & 5570 & 11800 & 5170 & 9040 & 20800 & 41000 & 18400 & 39200 \\
\hline Odour emission/pig (DT ${ }_{50} \mathrm{~m}^{3} \mathrm{~h}^{-1} \mathrm{pig}^{-1}$ ) & 35200 & 75000 & 32700 & 57600 & 69400 & 149000 & 66000 & 141000 \\
\hline Emission reduction/pig (\%) & 49 & 50 & 50 & 59 & n.a. & n.a. & n.a. & n.a. \\
\hline
\end{tabular}

n.a. = not applicablc.

of the panel members. This implies that the threshold is a barely detectable odour. The number of times a sample has to be diluted to reach the threshold level is a measure of the relative strength of the odour and is denoted by $\mathrm{DT}_{50}$. This is a non-dimensional quantity since it is simply a ratio of odourless to odorous air.

The relative odour strength (DT 50 ) times the ventilation rate of the building $\left(\mathrm{m}^{3} \mathrm{~h}^{-1}\right)$ results in the odour emission ( $\mathrm{DT}_{50} \mathrm{~m}^{3} \mathrm{~h}^{-1}$ ). This can be regarded as the total odour load per unit of time leaving the building. Finally, the odour emission can be used in atmospheric dispersion models in order to calculate the odour threshold distance.

Table 2 shows the results of the experiments as well as other data relevant to the piggeries at the time of sampling. When the odour emissions are compared for the two piggeries, on the same date, it can be concluded that the installation of filter nets reduced the odour emission per pig by approximately $50 \%$.

\subsubsection{Capital investment}

\subsection{Economic aspects}

In Holland two types of stalls are in use. The older types are arranged with longitudinal channels (Fig. 3) while the newer ones have transverse channels (Fig. 4). It is usual for the slurry to be stored under the slats in channels of about $1.5 \mathrm{~m}$ depth.

Table 3

Calculation of extra capital investment of the filter system

\begin{tabular}{|c|c|c|c|c|}
\hline \multirow[b]{3}{*}{ Number of pigs } & \multicolumn{4}{|c|}{ Piggery with filter and removal system } \\
\hline & \multicolumn{2}{|c|}{ Lomgitudinal channels } & \multicolumn{2}{|c|}{ Transverse channels } \\
\hline & 500 & 1000 & 500 & 1000 \\
\hline \multicolumn{5}{|l|}{ Extra: } \\
\hline Filter and removal system $£$ & 11610 & 17360 & 18540 & 35250 \\
\hline Storage of dung and liquid outside the stall $£$ & 2950 & 4770 & 2950 & 4770 \\
\hline Total (extra) $f$ & 14560 & 22130 & 21490 & 40020 \\
\hline \multicolumn{5}{|l|}{ Savings: } \\
\hline Shallow channels $£$ & 3410 & 7610 & 2390 & 4770 \\
\hline Heating system $f$ & 2180 & 3270 & 2180 & 3270 \\
\hline Total (savings) $£$ & 5590 & 10880 & 4570 & 8040 \\
\hline Extra capital investment $f$ & 8970 & 11250 & 16920 & 31980 \\
\hline Extra capital investment $\mathrm{f} /$ pig place & 17.9 & $11 \cdot 3$ & $32 \cdot 8$ & $32 \cdot 0$ \\
\hline
\end{tabular}


In Table 3 the extra capital investment of the filter system is calculated for both types of stalls, each with 500 and 1000 animals. This comparative calculation shows that the capital investment, required for this separation system, varies between the two types of piggery. The high costs in piggeries with transverse channels result from the greater number of expensive driving units in the short channels.

\subsubsection{Annual costs}

The extra annual costs in comparison with the costs of slurry handling, were calculated. In this calculation, the annual costs were fixed in relation to the capital costs as follows:

\begin{tabular}{l|c|c|c|c}
\hline & Depreciation & Interest & Maintenance & Total \\
\hline Building structures & 5 & 4 & 2 & 11 \\
Equipment & 10 & 4 & 3 & 17 \\
\hline
\end{tabular}

Table 4

Extra annual costs/pig place for the filter system in comparison with under-slat slurry storage, $\mathfrak{f} /$ pig place

\begin{tabular}{l|c|c|c|c}
\hline \multirow{2}{*}{} & \multicolumn{3}{|c}{ Piggery with filter and removal system } \\
\cline { 2 - 5 } & \multicolumn{3}{|c|}{ Longitudinal channels } & \multicolumn{2}{c}{ Tronsverse channels } \\
\cline { 2 - 5 } Number of pigs & 500 & 1000 & 500 & 1000 \\
\hline & & & & \\
Filter system & 3.95 & 2.95 & 6.30 & 5.99 \\
Straw & 1.00 & 1.00 & 1.00 & 1.00 \\
Total (extra) & 4.95 & 3.95 & 7.30 & 6.99 \\
Building structures & 0.10 & 0.31 & -0.12 & 0.00 \\
Heating sytem & 0.74 & 0.56 & 0.74 & 0.56 \\
Fuel & 2.00 & 2.00 & 2.00 & 2.00 \\
Transport & 1.00 & 1.00 & 1.00 & 1.00 \\
Total (savings) & 3.84 & 3.87 & 3.62 & 3.56 \\
Extra annual costs/pig place & 1.11 & 0.08 & 3.68 & 3.43 \\
\hline
\end{tabular}

In addition to these costs and the costs for straw it is supposed that by installing the filter system savings are possible, for example, for fuel and transport of slurry. The costs of straw are calculated on the basis of $£ 56.80 / \mathrm{t}$ of chopped straw and a daily provision of $50 \mathrm{~g} / \mathrm{pig}$. The yearly costs for fuel are based on $15 \mathrm{~m}^{3}$ gas/pig place and a price of $£ 0.14 / \mathrm{m}^{3}$ of gas. The costs for transporting the lurry $\left(1.5 \mathrm{~m}^{3}\right.$ per pig place per year) are based on the price the farmer usually pays to the "Manurebank". It is assumed that the separated farmyard manure can be sold and that this income offsets the cost of field spreading the liquid.

This calculation confirms the expectation that piggeries with longitudinal channels are more attractive for this separation system than piggeries with transverse channels. Compared with the costs for slurry separation (see Introduction), separation with the filtersystem is, on the assumptions made, a good alternative.

\section{Conclusions}

1. A separation and manure removal system has been developed and tested over 2 to 3 years and 
has been shown to be reliable for practical application. The separation of the faeces and urine is very effective.

2. The separated faeces together with added straw are stackable. This straw manure has a high fertilizer value and is more suitable for transport over greater distances than slurry.

3. The liquid has a low fertilizer value. In cases where the liquid cannot be spread on arable land surrounding the piggery it can be more easily disposed to an aeration system than slurry.

4. This system offers the possibility of providing straw in pens with partly slatted floors. Straw contributes to the well-being and comfort of the animals.

5. With separation and daily removal of the solid manure, anaerobic processes will be prevented. This reduces odour emission around the stall and during spreading. Because odour is minimized, the ventilation in winter can be decreased while maintaining a good climate in the piggery without a rise in heating costs.

6. The system is more cost effective when installed in piggeries with long as opposed to short channels.

\section{References}

1 Poelma H. R. Het scheiden van dunne mest (Separation of slurry). Bedrijfsontwikeling 1979, 10(6)

2 Stuurgroep Mestproblematiek, N. C. B. Kostenraming van mestscheiding in een centraal mestverwerkingsbedrijf (Calculations of slurry separation in a slurry disposal centre), 1981

3 Veen, H. J. van. Ontwatering van varkensdrijfmest (Separation of pig slurry). Report TNO, Ref. no. 83-04380. October, 1983. Apeldoorn

4 Ishii, Y. Separation system of faeces from urine in pigpen using slatted floor. Farming Japan 1980, 14(1): $41-44$

s Kurc, R. Einstreulose Nutzverhaltung ohne Gülle-anfal (A housing system without slurry production). Agrartechnik 1979, 29(3): 124

6 C.V.P.-Tilburg. Enquête verwarmingskosten mesterij $80^{\circ} 81$ (Inquiry into heating costs in piggeries '80/81), May 1982

7 Bruce, J. M. A suggestion for a ranked classification for floors of livestock buildings based on the conductive heat loss from recumbent animals. Proceedings Symposium "Animal housing-injuries due to floor surfaces". Cement and Concrete Association. Slough, England, 1978, pp. 123-131

- Buré, R. G. Measuring the well-being of pigs in different housing systems. In Livestock Environment. Proceedings of the Second International Livestock Environment Symposium 1982

- Buré, R. G.; van de Kerk, P.; Koomans, P. Het verstrekken van stro, compost en tuinaarde aan mestvarkens (The Supply of Straw, Compost und Garden Mould to Fattening Pigs). IMAG-Publikatie 190, December 1983

10 Ekesbo, I. Animal waste and its influence on animal hygienc. 1980 FAO Consultation on the European Cooperative Network on Animal Waste Utilization, Encl. 6, October 1980

1 Robertson, A. M. Effect of ventilation on the gas concentration in a part-slatted piggery. Farm Building $R \& D$, Studies 1971, May: 17-28

12 Ouwerkerk, E. N. J. van Bouwfysisch Computemodel vor Veestallen (Computing Program Building Physics (Cattle Stalls)). IMAG Jaargang 1981. Vechouderij en Milieu

13 Kroodsma, W. Separation of pig faeces from urine using synthetic netting under a slatted floor. The Proceedings of the 4th International Symposium on Livestock Wastes, 1980, pp. 419-422

14 Kroodsma, W. Trennung von Fäkalien und Harn in cinem Schweinestall mit Spaltenboden (Separation of faeces and urine in a piggery with slatted floors). Bericht über die 7. Arbeitstagung "Fragen der Güllerei', 1918, III. Band, pp. 761-771

15 Kolenbrander, G. J.; de Ia Lande Cremer, L. C. N. Stalmest en Gier (Farmyard Manure and Liquid Manure). Instituut voor Bodemvruchtbaarheid-Groningen, 1967

16 Spoelstra, S. F. Microbial aspects of the formation of malodorous compounds in anaerobically stored piggery wastes. Proefschrift, Agricultural University. Wageningen, December 1978

17 Frijters, J. E. R.; Beumer, S. A. L.; Klarenbeek, J. V.; Jongebreur, A. A. Psychophysical methodology in odour pollution research: the measurement of poultry house detectability and intensity. Chemical Senses and Flavour 1979, (4): 327-340

18 Klarenbeek, J. V. Odour measurements in dutch agriculture: current results and techniques. Research Report 82-2, Institute of Agricultural Engineering. Wageningen, 1982 